\title{
EXTERNAL AUDITOR AS A “FRIEND” OF THE AUDIT CLIENT: HOW TO TURN AUDIT COSTS INTO A USEFUL INVESTMENT?
}

\author{
Kosana Vićentijević, Danka Stefanović \\ Faculty of Business in Belgrade, Singidunum University, Belgrade, Serbia
}

\begin{abstract}
:
External audit is legally required for a certain number of business entities. It is not free - it is paid by the business entity, and the results of the external audit are generally used by external users of accounting information. However, by setting the proper relationship between the external auditor and the audit client, the latter can achieve great number of benefits: in the first place in order to increase the quality of financial reporting. In addition, the external auditor is bound by audit regulations to inform persons responsible for the management about his/her views in relation to the relevant accounting practices of the audit client, and to inform persons responsible for the organization as well
\end{abstract} as the management of the audit client about the observed deficiencies in internal controls.

\section{Key words:}

external audit, financial reporting, auditor, internal control, quality of financial reporting.

\section{INTRODUCTION}

In Serbia, an external audit of financial statements is legally required for regular annual financial statements of large and medium-sized legal entities, public companies (regardless of their size), as well as any legal entity or entrepreneur whose business income earned in the previous fiscal year exceeds 4.4 million EUR in RSD. In addition, the audit of consolidated financial statements is required for parent entities which draw up consolidated financial statements (Article 21 of the Audit Act, RS Official Gazette, No $62 / 2013)$. It is about 4,000 taxpayer audits. Obligingness of audits of financial statements of listed business entities is logical because the public is (directly or indirectly) interested in those reports. And it's not enough that these financial statements are accurate the public also has to consider them accurate. Public confidence in the reliability of the financial statements of the company depends on the public perception of the external auditor as an independent expert (US Securities and Exchange Commission, 2000).

Visible characteristics of the external audit of the financial report is that it is not free - it is paid by the business entity, and the results of the external audit are, generally, used by external users of financial statements in the first place. This paper has two hypotheses:

H1: that in our circumstancies an audit taxpayer does not use the full potential of the external audit and

$\mathrm{H} 2$ : that an audit taxpayer can increase the benefits of the external audit.

For the purposes of this paper the research of audit taxpayers was undertaken and the results of it support stated theory about the lack of use of the external audit potential. ${ }^{1}$

\section{COST OF EXTERNAL AUDIT AND ITS BENEFITS}

In the process of financial statements auditing most visible participants are: external auditors, accountant of audit taxpayers as well as management and management bodies of audit taxpayers. Audit success, measured by the ratio of costs and benefits, primarily depends on the attitude towards the revision of all these participants.

The cost of external audit of financial statements is directly paid by the audit taxpayer. There are two ways to express the cost of external audit: through the fee that is paid to the external auditor and through the "lost" time of employed audit taxpayers for preparing data for external auditor (there are of course other material 1 The survey was conducted in September 2014. costs of external audit in the audit taxpayers, mostly in the form of the cost of photocopying documents ). The most visible result of an independent audit of financial statements work is a document in the form of a "report of the independent auditor." The question is whether this is the only benefit obtained for the amount paid for the audit as well as who has the most benefits from this document: whether the benefits of this document is primarily used by the audit, who, primarily, bears the cost of the audit, or whether other users have the primary benefit of this document (owners of capital, potential investors, the public...)? Should avoided payment of the punishment for not contracted and done audit be included in benefits for business company?

It is certain that audit can be seen from this point of view as well, but if the management of an audit taxpayer sees audit in this way, it is quite possible that they will not put any effort in using it for improving their business.

Strictly speaking, the performance of the external audit has potential benefits for business of an audit taxpayer, as well. In order to turn them into realized ones, i.e. to audit costs into a useful investment there are several prerequisites:

1. that audit taxpayer knows what are the possible results of an independent audit of the financial statements, i.e. which are the potential benefits from it,

2. that everyone involved in the process of auditing knows what are the obligations of each participant in this process and what can and must be done within the audit and

3. there must be awareness among all stakeholders that the audit should be handled professionally and improve the work they do.

\subsection{The potential benefits of external audit of financial statements}

The practice of external audit of Financial Statements in the Republic of Serbia does not have long tradition, as is the case with market-developed countries. Therefore, it often happens that the management (and owners) of the audit taxpayer do not understand the real reasons for conducting the audit. It's one of the reasons why today the external audit of a large number of audit taxpayers is understood as the imposed obligation an additional (unnecessary) expenditure. Typically, this is a situation when the same person is both the owner and manager of a legal entity. In this case that person does not "see" the purpose of the audit, because both, the use of funds and financial reporting about them, are in his hands. To them external audit may only be the obstacle for possible "creative" financial reporting aimed at reducing tax liability of legal entity. Besides, 
it was noticed that in the audit practice, sometimes, audit taxpayers (their menagement or its administration) have expectations of auditors which are outside the scope of the financial statements audit. For example, within the scope of the audit there is not an assessment of successful performance of an audit taxpayer and the auditor should not be expected, or demanded, to provide information about this matter to audit taxpayer management; the possibility to require such information from the auditors is not excluded, but it should be based on his re-engagement (Petrović, 2010).

The potential benefits of external audit by the taxpayer audit are:

- developing the quality of financial statements and financial reporting process,

- improving the system of internal control,

- possible detection of fraud action, etc.

In order to achieve these benefits, the first prerequisite is that the relevant employees of the audit taxpayer are knowledgeable about them, because then they will expected from auditors. For example, they should know that the independent auditor report is not the only written report which they obtain from the auditor. Furthermore, they need to know which auditors' activities will lead to the development of these benefits.

\subsection{The auditors' activities which may create the potential benefits of external audit}

As part of the audit, the auditor is required to carry out certain activities which, consequently, can improve the financial reporting process of audit taxpayers, as well as his business.

The audit process, according to the paragraph 290.169. of the "Code of Professional Ethics for Professional Accountants "... requires discussion between the audit firm and management of audit taxpayers, which may involve discussion about:

- application of accounting standards or policies and publishing requirements in the financial statements;

- appropriateness of financial and accounting control and the methods used in determining the amount of shown assets' amount and liabilities...

It is essential that employees of the audit taxpayer know that those two activities are considered normal part of the audit process and that it is indisputable that they can significantly improve the quality of financial statements (and business). Hence, if initiative for discussion about these topics lacks, it should be initiated by employees in audit taxpayer.

Further in this paper we will present three international auditing standards of which the knowledge is essential not only for auditors, but they must be also known by audit taxpayers, because they can contribute to the improvement of the process of financial reporting and the business of audit taxpayers. Namely, if activities required by those standards lack from the part of auditors, the employees of audit taxpayer should insist on them.

ISA 250 Consideration of law and regulations in an audit of financial statements - Compliance of audit taxpayers' business performance with the law regulations relevant to that performance can prevent the payment of penalties and the emergence of other damage to the audit taxpayers. That is why it is important for the management of the audit taxpayer to know that in planning and performing the audit the auditor is required to consider this issue and that, in the case of doubt that there is a lack of compliance, auditor is required to discuss this issue with the management of audit taxpayer. This standard requires from the auditor to notify responsible persons in management as soon as possible when encounter cases of non-compliance with laws and regulations.

ISA 260 Communication with those charged with governance - This standard requires from the auditor to submit, among other things, the important findings of the audit to persons authorized to manage the audit taxpayers. Below we quote three examples of reports that illustrate how an auditor can influence the quality of financial reporting or the improving of the business performance of the audit taxpayers. (Petrović, 2010): a) selection or change of significant accounting policies or practices that have, or may have, a material effect on the financial statements of the audit client - an example of this statement may be:

"For subsequent evaluation of plants and equipment you have chosen the acquisition cost model. In terms of continuing price growth of plants and equipment, such a policy does not provide real data on the value of the fixed assets of your company, which affects their value in the financial statements."

b) any materially significant uncertainties related to events and conditions that may provoke doubt in the ability of the audit client to continue its business according to principle of business continuity - an example of this statement may be:

"Because of the amount of the Company's indebtedness we point out the significant risk which even in the case of minor disturbances in business performance will not be able to meet its obligations to creditors. This could jeopardize its further performances and survival."

c) disagreement with the management of the audit client in matters that, individually or summarized, may be of importance to the financial statements of the audit client or the report of the independent auditors. These reports include consideration of whether these issues are resolved or not, and their importance - example of this report may be:

"We believe that you are required to calculate provisions for severance pay. Non-calculation of these provisions will result in a material misstatement in the financial statements."

ISA 265 Communicating Deficiencies in Internal Control to Those Charged with Governance and Management - Auditors should promptly report in writing the important deficiencies in internal control that they discovered during the audit to persons authorized to manage. Auditor can firstly report these deficiencies orally to persons authorized to manage, in order to help them in taking measures for timely corrections and reductions to minimal risks of significant misstatement and possible damage to the audit taxpayers - an example of this statement may be:

"We believe that in the process of production recording there

is a significant lack of internal control system: the deviation in the cost of materials is neither determined nor analyzed comparing to the norm-making materials, which can lead to misuse."

The existence of awareness among all stakeholders that the audit should act professionally and improve the work they do - It is not a rare situation that accountants do their job the way it was done by their predecessors and plan to train their successors to perform work in the same way. The only thing that changes is the means with which they work: from calculating machines to computers. If the legal entity is not the audit taxpayer, the formation of "self-isolated" accountants is possible. In this case the accountants are not aware that their profession also changes and evolves. In this sense, the arrival of the auditor at the audit taxpayers may mean arrival of new information about the status and progress of the accounting profession. A prerequisite for this is that the auditors are also persons who are professionally competent and who want to share their knowledge with others. Undoubtedly the auditors do not share their knowledge from the field of financial reporting to accountants of audit taxpayers only because they are good and humane people. Doing this they facilitate their work of audit in the following years at the same audit taxpayer. This means that the interests of the two sides can coincide, which should be used in order to improve the quality of financial reporting process.

\section{METHODOLOGY AND RESULTS OF CONDUCTED SURVEY}

For the purposes of this study, we conducted a brief survey in September 2014. The primary method of data collection was 
anonymous questionnaire with different kinds of questions (closed and open-ended questions). Questionnaires were distributed to accountants who are employed in legal entities which are audit taxpayers. The survey was conducted on the territory of the Republic of Serbia, in the following cities: Belgrade, Novi Sad, Subotica and Valjevo. Fifty-six accountants were tested. From the obtained questionnaires, three of them were not included in the analysis of the results because the survey was not completed correctly.

The questions were the following:

1. Are you familiar with the requirements of ISA 250, 260 and 265?

Replies: 45 accountants responded negatively, 3 said that they were familiar and 5 that are partially familiar.

Comment: Without any doubt it arises that it is necessary to urgently improve accountants' knowledge in relation to these standards.

2. Did the auditor talk to you about the need to change the applied accounting policies to your financial statements on order to increase their quality?

Replies: 27 accountants responded that they were warned by the auditors that it was necessary to partly change their accounting policies: mainly it were advised to reevaluate property and equipment; 13 accountants responded that they spoke with the auditor about accounting policies, but that there was no objection by the auditor; 13 accountants stated that the accounting policies were not discussed with auditor.

Comment: The existence of the situation that accounting policies were not discussed with the auditor is unacceptable.

3. Did auditor point out the weaknesses in internal controls in your company to you or persons authorized to manage?

Replies: 15 accountants responded that their auditor reported weaknesses in internal controls in their company in writing, 38 accountants gave negative answer to this question. Thirteen of these thirty-eight accountants stated that they did not even discuss the internal controls with the auditor.

Comment: Given the importance of internal controls for the performance of the a company it is very important that they also be a subject to discuss with the auditor.

4. Have you learnt something new and useful for your business from the auditor?

Replies: 32 accountants answered positively and 21 negatively. Accountants who responded negatively stated that the main reason was insufficient professional competence of auditors - usually they worked with young people who are not authorized auditors.

Comment: We believe that it is necessary to fix the said relationship. A prerequisite for this is the engagement of audit firms which will find the right balance of authorized auditors engagement.
5. On the scale from $\mathbf{1}$ to $\mathbf{1 0}$ (where $\mathbf{1 0}$ is the best mark) assess if the external audit has contributed to quality improvement of the of financial statements that you write. Reply: The average score was 4.3 .

Comment: Reported average score indicates that there is room and that it is necessary to implement different activities so that expenditures for audit represent an investment which raises successfulness of business performance of audit taxpayers and improves the quality of their financial statements.

\section{CONCLUSION}

The management of an audit taxpayer, an accountant and an auditor are on the same mission: a qualitative financial reporting. In our conditions there has not yet been sufficiently developed awareness about the importance of audits for improving the quality of financial reporting and improving the business performance. Conducted survey confirmed the initial hypothesis that in our situation audit taxpayer does not use all the potential of the external audit in order to improve the financial reporting process. It is also found that there is space and that it is necessary to conduct activities that will ensure that the costs of the audit are an investment that raises successfulness of business performance of audit taxpayers and improves the quality of its financial statements, which confirms the second hypothesis, as well.

\section{REFERENCES}

[1] International Auditing and Assurance Standards Board, "Handbook of International Quality Control, Auditing, Review, Other Assurance, And Related Services Pronouncements", 2014, (Accessed: November 1, 2014.), [Available at: www.ifac.org/publications-resources/2014-handbook-international-quality-control-auditing-review-other-assurance-a]

[2] International Ethics Standards Board for Accountants, "2014 Handbook of the Code of Ethics for Professional Accountants", 2014, (Accessed: November 1, 2014.), [Available at: https://www.ifac.org/publications-resources/2014-handbook-code-ethics-professional-accountants-a]

[3] Narodna skupština Republike Srbije, „Zakon o reviziji“, 2014. godine, (Accessed: November 1, 2014.), [Available at: http://www.parlament.gov.rs/akti/doneti-zakoni/donetizakoni.1033.html]

[4] U.S. Securities and Exchange Commission, SEC Release 337919 (November 21, 2000) "Revision of the Commission's Auditor Independence Requirements"), (Accessed: September 16, 2014.), [Available at: www.ifac.org\%2Fsites\%2Fdefa ult\%2Ffiles\%2Fdownloads\%2Fa035-2010-iaasb-handbookisa-620.pdf]

[5] Z. Petrović, Međunarodni standardi revizije, Univerzitet Singidunum, Beograd, 2010. godine, [Available at: http://www. singipedia.singidunum.ac.rs/content/442-Medunarodnistandardi-revizije]

\title{
EKSTERNI REVIZOR KAO “PRIJATELJ” KLIJENTA REVIZIJE: KAKO TROŠKOVE REVIZIJE PRETVORITI U KORISNO ULAGANJE?
}

\author{
Kosana Vićentijević ${ }^{1}$, Danka Stefanović ${ }^{2}$ \\ ${ }^{1}$ Poslovni fakultet u Beogradu, Univerzitet Singidunum, Danijelova 32, Beograd, Srbija, kvicentijevic@singidunum.ac.rs \\ ${ }^{2}$ Poslovni fakultet u Beogradu, Univerzitet Singidunum, Beograd, Srbija, dstefanovic@singidunum.ac.rs
}

\begin{abstract}
Apstrakt:
Eksterna revizija je zakonski obavezna za određeni broj privrednih subjekata. Ona nije besplatna - plaća je privredni subjekt, a rezultate eksterne revizije uglavnom koriste eksterni korisnici računovodstvenih informacija. Međutim, postavljanjem pravilnih odnosa između eksternog revizora i klijenta revizije mogu se ostvariti brojne koristi po klijenta revizije: prvestveno u pravcu povećanja kvaliteta finansijskog izveštavanja. Sem toga, eksterni revizor je revizorskom regulativom u obavezi da licima zaduženim za upravljanje saopšti svoje stavove u vezi sa bitnim računovodstvenim praksama klijenta revizije, kao i da o uočenim nedostacima u internim kontrolama saopšti licima zaduženim za upravljanje i menadžmentu klijenta revizije.
\end{abstract}

\section{Ključne reči:}

eksterna revizija,

finansijsko izveštavanje, revizor,

interna kontrola,

kvalitet finansijskog izveštavanja 